\title{
Analysis of School Teachers' Practices for Quality Education in View of Their Head Teachers at Secondary Level
}

\author{
Hafiz Amanullah \\ PhD Scholar Education \\ The Islamia University of Bahawalpur, Pakistan \\ Email: hafezaman@gmail.com
}

Prof. Dr. Muhammad Aslam Adeeb

Pro-Rector, NCBA\&E, Bahawalpur Campus, Pakistan

Doi:10.5296/ijld.v4i4.6177 URL: http://dx.doi.org/10.5296/ijld.v4i4.6177

\section{Introduction}

The quality of education today seems globally to be the most prioritized area in the field of education as the provision of purposeful and high quality education appears to be the major concern of the countries all over the world. The Worlds Education Forum in Dakar (2000) pledged to provide quality education in the words: "Improving all aspects of the quality of education and ensuring excellence of all so that recognized and measurable learning outcomes are achieved by all, especially in literacy, numeracy and essential life skills". (Article 7(vi)). The Recife Declaration of the E-9 Project (2000) and The Beijing Declaration of the E-9 Project on ICT and EFA (2001) reaffirmed its commitment to the provision of quality education. South Asian Ministerial Meeting at Katmandu in April (2001) declared the matter of quality, most prioritized area in the field of education. Keeping in view the international concern and future needs of the country, the Government of Pakistan also took some measures to improve the quality of education. All educational policies and plans in Pakistan lay a great emphasis on the quality of education. Education Sector Reforms (2001-2005) introduced a number of strategies to enhance the quality of education through reformed curriculum, better teachers and an efficient examination system. Jatoi (2004), Shami and Hussain (2006) and, (DSD) Directorate of Staff Development (2008) agree that quality education in Pakistan is the matter of availing resources, and attaining the required standards through the best utilization of them. Recently introduced National Education Policy (2009) lays a great emphasis on raising the quality of education by improving teacher quality, curriculum reform, quality in textbooks and learning materials, improving student assessment, attaining standards in the learning environment and matching with the labour market. While keeping in view all the declarations, reforms and measures at national as well as international level, the quality of teacher seems the basic need of all other factors contributing to enhance the quality of education because the teachers remain responsible to implement all educational reforms at gross root level.

Thus, the active role of teacher may improve the quality of education and this active role is directly or indirectly owing to the quality of teacher. Anees (2005) considers teacher one of the most important factors for the implementation of all the educational policies and plans at gross root level. So, teachers' practices (activities) for quality education in classroom as well as in the institution seem to have positive and pragmatic effect on the quality of education. What is practice? According to Amanullah (2009) performing duties, meeting with responsibilities and 
doing a lot of activities seem to be some of the key engagements of the teacher in the institution and these engagements may be called teachers' practices. Hussain (2004) categorized teachers' functions in the institution into academic functions, professional functions and social functions. It seems clear that the functions deal with teacher's daily routine matters and so they may be called teacher's practices in the educational environment. Smith, Ewing and Cornu (2003) enlisted teacher's practices in four categories such as, relating to profession, community and society, colleagues and parents. Brown, Race and Smith (2004) focused on teacher's practices relating to students. Capel, Leask and Turner (2001), Dasgupta (2002) Holmes (2005) and Gill (2007) emphasized on the practices of teaching in the classroom while Chaplain (2003), Martinez (2004), Packard and Race (2005) and Elkin (2006) insisted much on the practices in the institution accompanied with classroom practices.

After the above discussion, it appears quite justified to say that teachers' practices are a vital ingredient of not only pedagogical environment and quality of education but also of the whole system of education. There may be no quality if teachers' practices are not according to the needs and requirements of quality education. Thus, teachers' practices must be made more and more target oriented so that it might be possible to attain the standards of high quality education. That is why, the present study targeted to evaluate the practices of the school teachers about the attainment of quality education.

\section{The Objectives}

The major focus of the study was to examine the practices of secondary school teachers in view of their heads for quality education at secondary level in the province of Punjab, Pakistan. The objectives of the study were:

(I) To study the teachers' practices in classroom for quality education at secondary level,

(II) To find out teachers' practices out of classroom for quality education at secondary level,

(III) To compare the classroom and out of classroom practices of teachers for quality education,

(IV) To suggest some measures to improve teachers' practices for quality education at secondary level.

\section{Methodology}

The population of the present study consisted of school head teachers of all male and female, urban and rural secondary schools in the province of Punjab, Pakistan. The study was delimited to only head teachers male and female, urban and rural, of public secondary schools.

There are nine administrative divisions of the Punjab province of Pakistan, and three out of the nine divisions Sahiwal, Faisalabad and Bahawalpur, were randomly selected for the study. These three divisions consisted of nine districts and three districts out of the nine Okara, Bahawalpur, Faisalabad were randomly selected to collect data. The sixteen schools equal in number urban and rural, male and female from each district were randomly selected. As the big question of this study was to find whether teachers' practices in view of their head teachers are according to the needs and requirements of quality education or not? So, the target population was consisted of head teachers. Thus, 48 head teachers of secondary schools was the sample of the study but 42 were possible to be contacted and the others could not be contacted due to some limitations. It was a survey type study and questionnaire was chosen as a research tool to collect data. A pilot study was conducted to make the questionnaire valid and reliable. According to the suggestions of the experts, teachers and researchers at the Education Department of The Islamia University of Bahawalpur, Pakistan it was improved and then it administered at 8 urban secondary schools ( 4 male, 4 female) in Bahawalpur City. The analysis 
of the pilot study was done using SPSS software version 16 and Cronbach Alpha (reliability of questionnaire internal consistency) value was found to be 0.940 . The value was strongly significant as the standard value according to Feldmann et al (2007) for the Cronbach Alpha is 0.70. After this, the questionnaire was launched in the field for collection of the data. The collected data were analyzed with the help of SPSS software version 16 using statistical formula of simple mean. Thus, upon the basis of results, suggestions and recommendations were made.

\section{The Results and Discussion}

Teachers' practices to contribute the quality of education were divided into two main categories, practices in classroom and practices out of the classroom. The practices towards quality education in classroom were about teachers' clear concepts and command on the subjects they teach, interesting lesson presentation, daily lesson preparation and planning, sufficient explanation of the topics they teach, usage of instructional material during teaching, students' involvement during teaching, equal treatment to all students in class, importance of students' opinion, skillful solution of classroom problems, positive attitude towards problem solving, sense of duty and responsibility during teaching, appropriate communication skills and usage of understandable language for students in classroom. Teachers' practices for quality education out of the classroom were about teachers' cooperation with colleagues, interest in school activities other than teaching, in time arrival to and departure from school, regular class taking, allocation of teaching subjects according to teachers' interests, teachers' satisfaction with salary structure and teaching profession, discussion with head teacher for teaching learning, head teacher-teacher cooperation, mutual understanding of teachers and head teachers and, teacher-student cooperation.

The following tables describe teachers' practices for quality education in view of their head teachers. There is description of classroom and out of classroom practices district wise as well as the comparison between them with respect to locality (urban and rural) and gender (male and female).

\section{Table 1: Practices in classroom and out of classroom (Gender wise)}

The table-1 shows that mean score of male teachers' practices out of the classroom in view of

\begin{tabular}{cccc}
\hline Gender & Frequency & $\begin{array}{c}\text { Practices in classroom } \\
\text { (Mean) }\end{array}$ & $\begin{array}{c}\text { Practices out of classroom } \\
\text { (Mean) }\end{array}$ \\
\hline Male & 21 & 39.95 & 40.52 \\
\hline Female & 21 & 39.86 & 40.81 \\
\hline
\end{tabular}

their head teachers for quality education is 40.52 which is better than their mean score 39.95 of practices in classroom. So, male teachers' practices out of classroom in view of their head teachers are better than their practices in classroom for quality education. The mean score of female teachers' practices out of classroom in view of their head teachers is 40.81 which is better than their practices in classroom 39.86. So, female teachers' practices out of classroom for quality education are better than their practices in classroom. It can be concluded that male and female teachers' practices out of classroom for quality education in view of their head teachers are better than their practices in classroom. It is found that there is no significant difference between male and female teachers' practices of both fields (in classroom and out of classroom) for quality education but male teachers' practices in classroom are slightly better than female teachers and female teachers' practices out of classroom for quality education are slightly better than male teachers. 
Table 2: Overall Practices (Gender wise)

\begin{tabular}{ccc}
\hline Gender & Frequency & Overall Practices (Mean) \\
\hline Male & 21 & 80.48 \\
\hline Female & 21 & 80.67 \\
\hline
\end{tabular}

The table-2 shows that mean score of female teachers' overall practices for quality education in view of their head teachers is 80.67 which is slightly better than mean score of male teachers' practices 80.48 . So, it can be concluded that there is no significant difference between male and female teachers' overall practices for quality education but female teachers' practices are slightly better than male teachers' practices.

Table 3: Practices in classroom and out of classroom (Locality wise)

\begin{tabular}{cccc}
\hline Locality & Frequency & $\begin{array}{c}\text { Practices in classroom } \\
\text { (Mean) }\end{array}$ & $\begin{array}{c}\text { Practices out of classroom } \\
\text { (Mean) }\end{array}$ \\
\hline Urban & 22 & 39.77 & 40.23 \\
\hline Rural & 20 & 40.05 & 41.15 \\
\hline
\end{tabular}

The table-3 shows that mean score of urban teachers' practices for quality education out of classroom in view of their head teachers is 40.23 which is better than mean score of their practices in classroom 39.77. So, urban teachers' practices out of classroom in view of their head teachers are better than their practices in classroom for quality education. The mean score of rural teachers' practices out of classroom in view of their head teachers is 41.15 which is better than their practices in classroom 40.05. So, rural teachers' practices out of classroom for quality education are better than their practices in classroom. It can be concluded that urban and rural teachers' practices out of classroom for quality education in view of their head teachers are better than their practices in classroom. It is found that rural teachers' practices for quality education in both fields (in classroom and out of classroom) in view of their head teachers are better than urban teachers.

Table 4: Overall Practices (Locality wise)

\begin{tabular}{ccc}
\hline Locality & Frequency & Overall Practices (Mean) \\
\hline Urban & 22 & 80.00 \\
\hline Rural & 20 & 81.20 \\
\hline
\end{tabular}

The table- 4 shows that mean score of rural teachers' overall practices for quality education in view of their head teachers is 81.20 which is better than mean score of urban teachers' practices 80.00. So, it can that rural be concluded teachers' practices are better than urban teachers' practices for quality education in view of their head teachers.

Table 5: Teachers' Practices in classroom and out of classroom

\begin{tabular}{lccc}
\hline Respondents & Frequency & $\begin{array}{c}\text { Practices in } \\
\text { classroom (Mean) }\end{array}$ & $\begin{array}{c}\text { Practices out of } \\
\text { classroom (Mean) }\end{array}$ \\
\hline Headteachers & 42 & 39.90 & 40.67 \\
\hline
\end{tabular}

The table- 5 shows the mean score of teachers' practices for quality education in classroom and out of classroom in view of their head teachers. The mean score of teachers' practices out of classroom is 40.67 which is better than their mean score 39.90 of in classroom practices for quality education. So, it is found that all the teachers' out of classroom practices are better than their in classroom practices for quality education in view of their head teacher. 
Table 6: Practices in Classroom and out of Classroom (District Wise)

\begin{tabular}{cccc}
\hline District & Frequency & $\begin{array}{c}\text { Practices in } \\
\text { Classroom } \\
\text { (Mean) }\end{array}$ & $\begin{array}{c}\text { Practices out of } \\
\text { Classroom } \\
\text { (Mean) }\end{array}$ \\
\hline Okara & 16 & 37.06 & 39.38 \\
\hline Bahawalpur & 12 & 45.00 & 44.08 \\
\hline Faisalabad & 14 & 38.79 & 39.21 \\
\hline
\end{tabular}

The table- 6 shows that mean score of teachers' practices for quality education out of classroom in District Okara is 39.38 which is better than their mean score 37.06 of practices in classroom. So, it is found that teachers' practices out of classroom in District Okara are better than practices in classroom. The mean score of teachers' practices in classroom for quality education in view of their head teachers in District Bahawalpur is 45.00 which is better than mean score 44.08 of out of classroom practices. So, it is found that at District Bahawalpur, teachers' practices in classroom are better than their practices out of classroom. The mean score of teachers' practices out of classroom for quality education in view of their head teachers in District Faisalabad is 39.21 which is better than mean score 38.79 of in classroom practices. So, it is found that at District Faisalabad, teachers' practices out of classroom are better than their practices in classroom for quality education in view of their head teachers.

Table 7: Overall Practices (District Wise)

\begin{tabular}{ccc}
\hline District & Frequency & Overall Practices (Mean) \\
\hline Okara & 16 & 76.44 \\
\hline Bahawalpur & 12 & 89.08 \\
\hline Faisalabad & 14 & 78.00 \\
\hline
\end{tabular}

The table-7 shows teachers' practices for quality education in view of their head teachers at the selected three districts. The mean score of teachers' practices of Bahawalpur District is 89.08 which is better than mean score 78.00 of teachers' practices in Faisalabad District. The mean score of Faisalabad District 78.00 is better than the mean score 76.44 of Okara District. So, it is found that teachers' practices for quality education in view of their head teachers in Bahawalpur District are better than the teachers' practices of other two districts.

\section{Findings}

The analysis of data presents a clear picture about teachers' practices for quality education at secondary level. Teachers' practices were divided into two main categories - practices in classroom and practices outside the classroom. The findings are as follows:

- Teachers' practices out of classroom for quality education in view of their head teachers are better than their practices in classroom.

- There is no significant difference between male and female teachers' practices of both fields (in classroom and out of classroom) for quality education but male teachers' practices in classroom are slightly better than female teachers and female teachers' practices out of classroom for quality education are slightly better than male teachers.

- There is no significant difference between male and female teachers' overall practices for quality education but female teachers' practices are slightly better than male teachers' practices.

- Urban and rural teachers' practices out of classroom for quality education in view of their head teachers are better than their practices in classroom. 
- Rural teachers' practices for quality education in both fields (in classroom and out of classroom) are better than urban teachers.

- Teachers' out of classroom practices are better than their in classroom practices for quality education in view of their head teacher.

- At District Bahawalpur, teachers' practices in classroom are better than their practices out of classroom.

- At District Faisalabad, teachers' practices out of classroom are better than their practices in classroom for quality education in view of their head teachers.

- Teachers' practices out of classroom in District Okara are better than their practices in classroom.

- Teachers' practices for quality education in view of their head teachers in Bahawalpur District are better than the teachers' practices of other two districts.

\section{Conclusion}

It is concluded that teachers' practices out of classroom for quality education in view of their head teachers are better than their practices in classroom. Female teachers' practices are better than male teachers and rural teachers' practices are better than urban teachers' practices. When teachers' in classroom and out of classroom practices are compared, it is concluded that out of classroom practices of teachers are better than in classroom practices. Teachers' practices at Bahawalpur District are better than both of the other selected districts and very poor at Okara District as compared to both of the other selected districts.

\section{Recommendations}

The following measures are suggested on the basis of analysis and findings of this study, suggestions by the respondents and observation of the researcher:

- There is need to improve teachers' practices for quality education at secondary level especially their practices in classroom.

- Teachers' out of classroom practices should be focused to improve the quality of education and unnecessary practices must be abandoned.

- Teachers' should pay attention to their professional development so that their practices might be made more and more fruitful.

- Teachers must be made aware of the modern concepts of the quality of education.

- Special refresher courses, seminars, and workshops are needed for making teachers' practices much focused for quality education.

- Activity based training sessions should be conducted to update teachers' knowledge, to make their understanding better and to enhance their skills to improve quality education.

- Teachers should be well equipped with instructional material required in the classroom so that they might be able to practice well in classroom and in the institution.

\section{References}

Academy of Educational Planning and Management, Ministry of Education, (2004). Study on Comparing School Performance to Understand Which Schools are Doing Better by Assessing and Comparing Quality of Education. Islamabad: Government of Pakistan.

Amanullah, H. (2009). Analysis of School Teachers' Perceptions and Practices for Quality Education at Secondary Level. M. Phil Thesis, Department of Education, The Islamia University of Bahawalpur, Pakistan.

Brown, S., Race, P., \& Smith, B. (2004). 500 Tips for Quality Enhancement in Universities and Colleges. New Delhi: Crest Publishing House. 
Capel, S., Leask, M. \& Turner, T. (2001). Learning to Teach in Secondary School:A Companion to School Experience. London and New York:Routledge Falmer.

Dasgupta, D. N. (2002). Practice Teaching. Jaipur:Pointer Publishers.

Hamidullah, M. (2005). Comparison of the Quality of Higher Education in Public and Private Sector Institutions in Pakistan. PhD Thesis, University Institute of Education and Research, University of Arid Agriculture Rawalpindi, Pakistan.

Hassan J. (2006). Education in Pakistan: White Paper Document to Debate and Finalize the National Education Policy. Islamabad: Ministry of Education.

Jatoi H. (2004). Study on Comparing School Performance to understand which Schools are Doing Better by Assessing and Comparing Quality of Education. Islamabad. Academy of Education Planning and Management Ministry of Education.

Karaagac, M. K., \& Threlfal, J. (2004). The Tension between Teacher Beliefs and teacher Practice: The Impact of the Work Setting. Proceedings of the $28^{\text {th }}$ Conference of the International Group for Psychology of Mathematics Education. Leeds:137-144.

Martinez, M. C. (2004). Teachers Working Together for School Success. Thousand Oaks:Corwin Press.

Ministry of Education, (2003). National Plan of Action on Education for All (2001-2015) Pakistan. Islamabad:Government of Pakistan.

Ministry of Education, (2003). Quality of Primary Education in Pakistan:Preparatory Document for the Ministerial Meeting of South Asia EFA Forum. Islamabad:Government of Pakistan.

Ministry of Education, (2004). Education Sector Reforms:Action Plan 2001-02, 2005-06. Islamabad: Government of Pakistan.

Ministry of Education, (2009). New Education Policy 2009. Islamabad: Government of Pakistan

Packard, N., \& Race, P. (EDS.). (2005). 2000 Tips for Teachers. New Delhi:Kogan Page India Private Limited.

Shami, P.A. Hussain, K.S. (2006). Learning Achievement: Quantitative and Qualitative Data. Islamabad: Academy of Educational Planning and Management, Ministry of Education.

Smith, S. G., Ewing, R., \& Cornu, R. L. (2003). Teaching: Challenges and Dilemmas. Australia:Nelson Australia Ptv. Limited. 